\title{
Connecting differential responses of native and invasive riparian plants to climate change and environmental alteration
}

\author{
Neal E. Flanagan, ${ }^{1}$ Curtis J. Richardson, and Mengchi Ho \\ Duke University Wetland Center, Durham, North Carolina 27708 USA
}

\begin{abstract}
Climate change is predicted to impact river systems in the southeastern United States through alterations of temperature, patterns of precipitation and hydrology. Future climate scenarios for the southeastern United States predict (1) surface water temperatures will warm in concert with air temperature, (2) storm flows will increase and base flows will decrease, and (3) the annual pattern of synchronization between hydroperiod and water temperature will be altered. These alterations are expected to disturb floodplain plant communities, making them more vulnerable to establishment of invasive species. The primary objective of this study is to evaluate whether native and invasive riparian plant assemblages respond differently to alterations of climate and land use. To study the response of riparian wetlands to watershed and climate alterations, we utilized an existing natural experiment imbedded in gradients of temperature and hydrology found among dammed and undammed rivers. We evaluated a suite of environmental variables related to water temperature, hydrology, watershed disturbance, and edaphic conditions to identify the strongest predictors of native and invasive species abundances. We found that native species abundance is strongly influenced by climate-driven variables such as temperature and hydrology, while invasive species abundance is more strongly influenced by site-specific factors such as land use and soil nutrient availability. The patterns of synchronization between plant phenology, annual hydrographs, and annual water temperature cycles may be key factors sustaining the viability of native riparian plant communities. Our results demonstrate the need to understand the interactions between climate, land use, and nutrient management in maintaining the species diversity of riparian plant communities. Future climate change is likely to result in diminished competitiveness of native plant species, while the competitiveness of invasive species will increase due to anthropogenic watershed disturbance and accelerated nutrient and sediment export.
\end{abstract}

Key words: desynchronized cycles; exotic; floodplain; hydrology; introduced species; plant community; temperature; watershed.

\section{INTRODUCTION}

Biological invasions are important consequences of human-induced changes to ecosystems across the globe (Vitousek et al. 1997, Chapin et al. 2000). In the United States, invasive species cause ecological damage of almost $\$ 120$ billion per year and imperil $42 \%$ of the species on threatened or endangeredspecies lists (Pimentel et al. 2005). Climatic shifts and land-use changes are recognized as key drivers of the spread of invasive species (Diez et al. 2012, Bellard et al. 2013). Recent studies have demonstrated a conclusive link between climatic alteration, biodiversity and the spread of nonnative species (Walther et al. 2002, Parry 2007, Williams et al. 2008, Dawson et al. 2011).

Riparian ecosystems are landscape focal points for interactions between climate and invasive species dispersal and establishment (Naiman and Décamps 1997, Pollock et al. 1998, Pyšek and Richardson 2006, Richardson et al. 2007, Murray et al. 2012, Catford et

Manuscript received 22 April 2014; revised 11 August 2014; accepted 15 August 2014. Corresponding Editor: C. Nilsson

${ }^{1}$ E-mail: nflanaga@duke.edu al. 2013). River corridors shape patterns of invasive propagule movement across entire landscapes via wind, water, and animal dispersal mechanisms (Nilsson et al. 1991, 2010, Pyšek and Prach 1993, Johansson et al. 1996, Charalambidou and Santamaría 2002, Richardson et al. 2007, Leuven et al. 2009, Säumel and Kowarik 2010). The major threats to biodiversity in wetland and riparian freshwater ecosystems include land use change, climate change, and biological invasions (Sala et al. 2000, Zedler and Kercher 2004, Pyšek et al. 2010). Riparian wetlands have a diverse microtopography and geomorphology which, along with variable hydroperiod, provide habitat for a wide range of life forms (Naiman and Décamps 1997). Wetlands are also landscape sinks for debris, sediments, nutrients, and propagules. In riparian wetlands, fluxes of materials along with flood events create frequent disturbance opportunities for the establishment of nonnative species resulting in high levels of invasion (Zedler and Kercher 2004).

The temperature and flood regimes of river systems are reflections of climatic conditions within their watersheds (Junk et al. 1989). Alterations of regional and catchment hydrology projected by global climate 
change models include increasing frequency and intensity of precipitation events driven by increased temperature (Easterling et al. 2000). In the southeastern United States, climate change is projected to increase surface water temperatures by $1-5^{\circ} \mathrm{C}$, and precipitation by $5-$ 30\% (IPCC 2001; HadCM2 [Johns et al. 1997]), while increased evapotranspiration may result in lower overall stream baseflows (Mulholland et al. 1997, Schindler 1997, Vörösmarty et al. 2000). Temperature regimes of freshwater ecosystems are projected to change in parallel with shifts in air temperature because of the tight relationships between air and water temperature (Pilgrim et al. 1998, Mohseni et al. 1999, Allan and Castillo 2007). Altered thermal regimes and hydrology are key climate-linked drivers of nonnative plant invasions in freshwater ecosystems (Sala et al. 2000, Hellmann et al. 2008, Rahel and Olden 2008, Heino et al. 2009).

In meta-analyses comparing invasive plant species to cooccurring native species, there are no statistically significant trends of superior growth performance for either category. Rather, the relative competitive ability of invasive species depends on site-specific growing conditions (Daehler 2003, Vilà et al. 2011). While many studies have examined the threat of invasive plant species to ecosystems, fewer have addressed how alterations of climate-driven environmental variables might differentially affect native and invasive assemblages (Thuiller et al. 2007). Though increased atmospheric $\mathrm{CO}_{2}$ typically enhances the competiveness of invasive species, other aspects of climate change and land use alterations exert greater influence on biodiversity and invasive species establishment (Sala et al. 2000). Climatic variables interact with life history to drive population responses; these interactions are both complex and setting specific, thus requiring use of observational studies to understand the response of species assemblages to climate change (Williams et al. 2008, Dawson et al. 2011). Observational studies across gradients of altered water temperature and hydroperiod provided insights into the relative importance of climate-linked environmental variables in determining outcomes of competitive interactions between established native riparian communities and alien plant species. The effect of cooling is often overlooked in studies linking invasive species and climate change. However, experimental examinations of both cooler and warmer temperatures are useful in reflecting extreme events and increased climatic variability (Shaver et al. 2000, Parmesan and Yohe 2003).

We present a study of naturally occurring wetlands located along anthropogenically warmed or cooled rivers in North Carolina and Virginia to examine linkages between flood regimes, water temperature, and riparian plant community structure. These experimental sites were selected to represent the range of current and predicted future climatic conditions in southeastern floodplains. We used existing environmental gradients produced by two classes of dams, hydroelectric dams drawing from epilimnion vs. hypolimnion, to examine effects of temper- ature and flood frequency on riparian plant communities and ecosystem functions. We focused on the effects of temperature gradients on invasive species, plant community shifts, and plant biomass. This approach allowed us to select sites with altered temperature and/or hydrologic conditions to fit our experimental design, without overlooking important ecosystem processes such as hydrochory (i.e., the passive dispersal of organisms by water [Nilsson et al. 2010]) that are crucial to determining the invasibility of natural wetlands. In this paper, we ask: what are the implications of altered water temperature and hydroperiod on the establishment, abundance, biomass and distribution of invasive species in river floodplain ecosystems? More specifically, we ask (1) How do native and invasive species differ in responses to alterations of environmental variables? (2) What is the relative importance of climate-linked environmental variables in structuring the composition and biomass of riparian plant communities? (3) How have hydrology and temperature affected the current community composition and the level of invasion of southeastern floodplain ecosystems at the regional scale? and (4) How will expected future alterations of temperature and hydrology drive the abundance of invasive species in these ecosystems?

\section{Methods}

\section{Site selection, methods and experimental analysis}

Twenty-four wetland sites on river flood plains throughout North Carolina and southern Virginia were selected to capture a range of water temperatures and altered hydroperiod. They were grouped into three experimental temperature treatments of "warm," "cold," and "reference" (reflecting ambient water temperature). Ten warm sites are positioned downstream of three reservoirs (Cowen's Ford, Kerr, and Gaston Dams) that are warmed by steam-turbine electrical power plants and/or submerged skimmerweirs (Olmsted and Bolin 1996) causing outflow to be drawn from the warmer reservoir epilimnion. Eight sites selected for the cold treatment are positioned downstream of two hydroelectric plants and outflow is drawn from cooler strata near the reservoir bottom (Smith Mountain, and Philpott Dams, Virginia). Six reference sites were selected in three unregulated watersheds with ambient water temperature regimes (Fig. 1). All dams had been in place for at least four decades. Initial surface water measurements and USGS records verified more than a $5^{\circ} \mathrm{C}$ difference in mean surface water temperatures between our warm and cold treatments. Additionally, sites were selected using the following screening criteria: (1) located within the Piedmont Level III Ecoregion (Griffith et al. 2002), (2) headwaters in the Blue Ridge Mountains of North Carolina and Virginia, (3) watershed land use that was primarily rural (forest and agriculture, Appendix A), (4) a high degree of hydrologic connectivity (frequent flooding), (5) similar nutrient regimes, (6) all cold and warm treatment sites were located downstream of large 

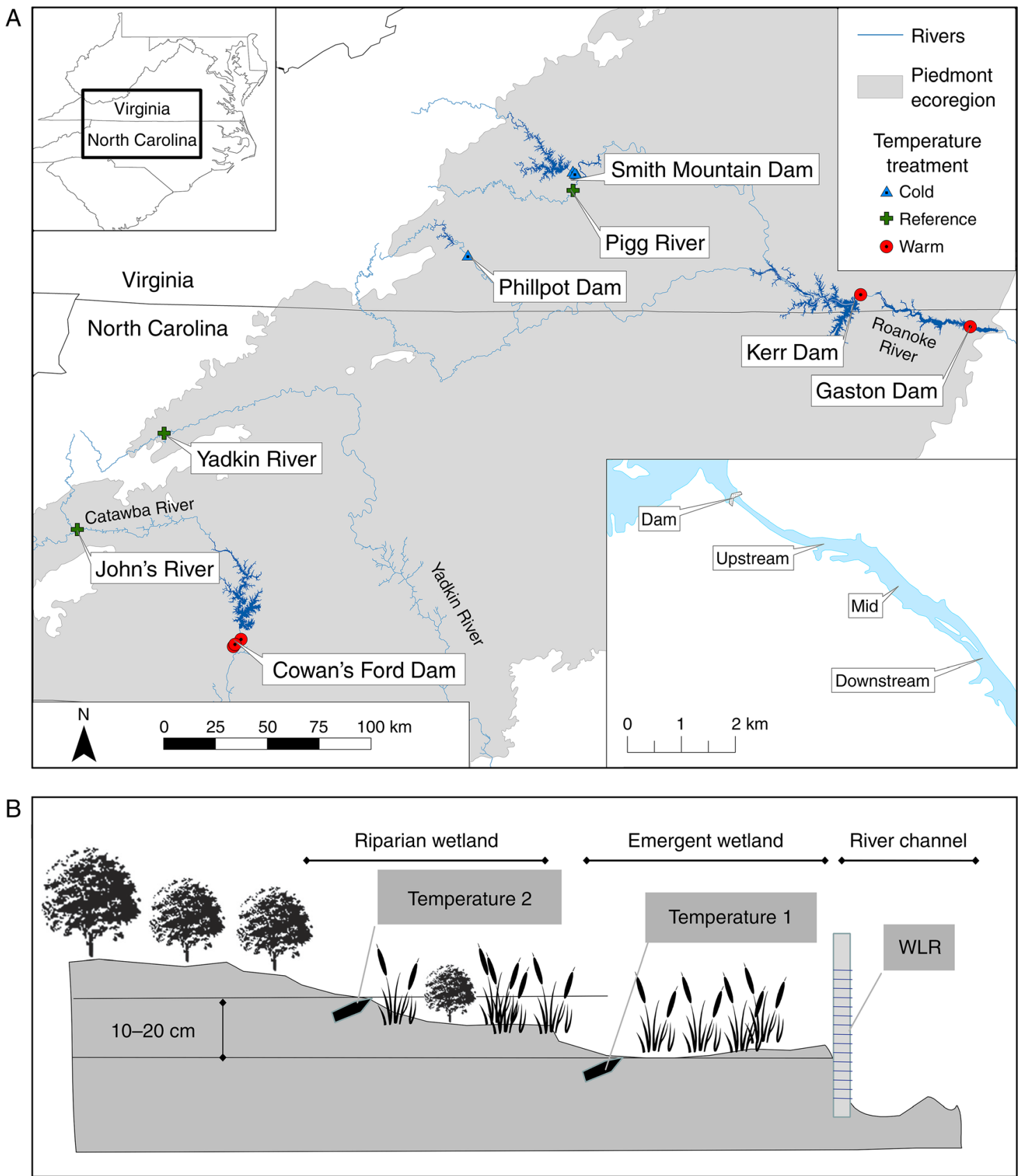

FIG. 1. (A) A map of the riparian study locations and sites on cold, warm, and reference streams in Virginia and North Carolina. Inset 1 in the top left corner shows the study area in the piedmont of North Carolina and Virginia in the southeastern United States. Inset 2 in the bottom right corner shows the typical layout of sites within a temperature gradient treatment. Upstream sites are located near a dam and have more extreme (warm or cold) soil and water temperatures; Mid (middle) sites and downstream sites grade toward regional ambient temperatures. (B) Site layout showing the position of temperature probes and water level recorders (WLR) within the emergent and riparian vegetation zones that occur at our sites, and a $10-20 \mathrm{~cm}$ difference in elevation between the emergent and riparian treatments.

reservoirs producing similar impacts on hydrochory, and (7) reference sites were located in free-flowing watersheds (Fig. 1A). For the remainder of this paper we will refer to locations as areas downstream of a specific dam within a temperature treatment (cold, warm) or a reference watershed, and sites as sampling points nested within a given location as part of gradient treatments (upstream, midstream, downstream) or hydrology treatments (emergent and riparian). There were a total of eight locations and 24 sites. Appendix A presents a summary of locations, sites, and treatments. 
We assigned locations to our temperature treatments based upon dam structural features and water temperature measurements taken in the field. For example, water temperatures at the cold locations are significantly cooler than those from the warm locations by $>5^{\circ} \mathrm{C}$ during the growing season. During most summer periods, the water temperatures at locations in the cold treatment (Smith Mountain Lake, Philpott Dam) are less than $20^{\circ} \mathrm{C}$, while summertime water temperatures at warm treatment locations exceed $25^{\circ} \mathrm{C}$. Dam features including power plant intakes with or without structural thermal modifications, i.e., submerged weirs, explain observed temperature differences.

In our experimental design we tested two treatment effects: temperature and hydrology. Within a given temperature treatment location (warm, cold, and freeflowing reference) we selected two sites (emergent and riparian) to sample for our hydrology treatment $(N=24)$. The riparian sites were approximately 10-20 cm higher than the emergent sites and experienced significantly shorter flood durations $(P<0.05)$. This difference in hydrology was reflected in a shift in plant community composition, but both treatments are dominated by emergent wetland forb and graminoid species. The emergent zone began at the lower boundary of persistent emergent vegetation and was dominated by sedges, reeds, and mudflat species. The riparian zone occurred at a slightly higher elevation where the plant community is dominated by grasses, clonal dominant species, and occasional woody shrubs (Fig. 1B).

In 2009, we established additional gradient sites at one warm and one cold dam to see if we could discern a predominant effect of temperature gradients on plant community structure. Locations downstream of a given dam and within the same hydrology treatment (riparian or emergent) varied little in terms of soils, hydrology, and propagule sources but did vary in temperature. Sites where water temperatures were more extreme (either hot or cold) occurred near the dam and temperature graded toward ambient with distance away from the dam. At each of these dams, one upstream and one downstream location was added to the existing central or midstream location (insert Fig. 1A) resulting in three gradient sites within each hydrology treatment site $(2 \times 3=6$ gradient sites at each dam). Our design can be summarized as a staggered nested design with a replicated large-scale temperature treatment having three levels (cold, warm, reference), and a replicated hydrology treatment having two levels (emergent and riparian) with additional temperature replicates along local-scale temperature gradients. Our design is summarized in Appendix A.

Plant surveys were performed in the fall of 2008 and the summers of 2009 and 2010 at all 24 sites. Surveys were performed on $10-\mathrm{m}$ transects using line intercept methods (Richardson and Vymazal 2001). All plants intercepting the line were recorded at $10-\mathrm{cm}$ intervals using a vertical plumb bob. The elevation of the beginning, middle, and end point of each transect was recorded using survey equipment and related to a fixed datum on the adjacent water-level recorder. Transects were arranged to be perpendicular to the elevation gradient within the emergent or riparian zones. All transect data from a given location were aggregated to produce a single community matrix of species count $\times$ site location. A summary of life forms of the 20 most important plant species in each temperature treatment is presented in Appendix A. In 2011, peak biomass samples were collected from all sites between 15 June and 30 July for estimates of peak aboveground biomass (PAB) of emergent macrophytes. Using $1-\mathrm{m}^{2}$ quadrats, all biomass was removed from the soil surface and stems were sorted by species. Samples were dried to a constant mass in a forced air oven at $70^{\circ} \mathrm{C}$ and weighed. Plant species were classified as invasive or native, with invasive species being those that are either listed as "introduced" in the USDA Plants Database (USDA, NRCS 2012) and/or those that occur on the Southeast Exotic Pest Plant Council list of exotic and invasive plant species (SEEPC 1996).

At each site, we measured a range of environmental variables that are likely to influence the establishment and growth of invasive wetland species including temperature, features of hydrology, soil nutrient content and availability, and soil texture (Zedler and Kercher 2004). All variables are described in Table 1 along with abbreviations used in the remainder of this study. To avoid pseudoreplication (Hurlbert 1984), we selected locations having distinct catchment areas and, except for adjacent riparian and emergent sites, are spaced least $1 \mathrm{~km}$ apart (Fig. 1). Within our sites, we selected riparian or emergent sites with statistically significant differences in hydrology (i.e., flood duration, Table 2). We calculated hydrology indices at each location using a continuous time series of water levels for the duration of the study. Our gradient treatment (upstream, midstream and downstream) is categorical and uses a natural gradient of temperature that ranges from extreme divergence from ambient conditions near the dam (upstream) to nearambient conditions at the downstream treatment. There were significant temperature differences between sites within the cold and warm treatments (Table 2).

We installed automatic water-level loggers at each location that were either the Telog Model PR 31 (Telog, Victor, New York, USA) or the Solinst Model 3001 (Solinst, Georgetown, Ontario, Canada), to record flood depth at 15-minute intervals. Flood depth, duration, rate of depth increase (flood power), and return interval for a given elevation was calculated after relating plant survey transects and quadrats to a vertical datum using survey equipment (Laser Level HL3A, Topcon Positioning Systems, Livermore, California, USA) and tying this datum to the water level recorder readings. Three replicate soil samples were collected from each site $(N=$ 72 ) in the fall of 2008 . Soil samples were stored at $4^{\circ} \mathrm{C}$ between sampling and analysis. Half of each core was dried at $105^{\circ} \mathrm{C}$ for $24 \mathrm{~h}$ to determine the moisture content. The remaining half was held at field moisture 
TABLE 1. Abbreviations and definitions of all model variables used to characterize the watersheds, hydrology, and soil in our statistical models.

\begin{tabular}{|c|c|c|c|}
\hline Group & Unit & Description & Method \\
\hline \multicolumn{4}{|l|}{ Watershed } \\
\hline Urb & $\%$ & areal fraction urban development & GIS \\
\hline $\mathrm{Ag}$ & $\%$ & areal fraction of cultivated land & GIS \\
\hline Undist & $\%$ & areal fraction of undeveloped, forested lands & GIS \\
\hline AREA & $\mathrm{km}^{2}$ & Watershed area & GIS \\
\hline SGDD & ${ }^{\circ} \mathrm{C}$ & annual cumulative soil growing degree day & temperature logger \\
\hline POINT $\mathrm{X}$ & degrees & longitude & GPS \\
\hline POINT_Y & degrees & latitude & GPS \\
\hline \multicolumn{4}{|l|}{ Hydrology } \\
\hline POWER & $\mathrm{mm} / \mathrm{h}$ & flood rate of water surface rise; flood power & hydrograph analysis and elevation survey \\
\hline FREQ & & proportion of inundated period & hydrograph analysis and elevation survey \\
\hline DEPTH & & average depth of inundation & hydrograph analysis and elevation survey \\
\hline DUR & minute & average duration of inundation & hydrograph analysis and elevation survey \\
\hline NUMFD & $\mathrm{yr}^{-1}$ & number of flood episodes per year & hydrograph analysis and elevation survey \\
\hline \multicolumn{4}{|l|}{ Soil } \\
\hline Sand & $\%$ & sand fraction by mass & cores, lab analysis \\
\hline Clay & $\%$ & clay fraction by mass & cores, lab analysis \\
\hline $\mathrm{BD}$ & $\mathrm{g} / \mathrm{cm}^{3}$ & Bulk density on oven-dry basis & cores, lab analysis \\
\hline LOI & $\%$ & loss on ignition by original dry mass & cores, lab analysis \\
\hline $\mathrm{C}$ & $\mu \mathrm{g} / \mathrm{g}$ & total carbon on oven-dry basis & cores, lab analysis \\
\hline CTP & $\mu \mathrm{g} / \mathrm{g}$ & total phosphorus on oven-dry basis & cores, lab analysis \\
\hline EXP & $\mu \mathrm{g} / \mathrm{g}$ & extractable phosphorus on oven-dry basis & cores, lab analysis \\
\hline $\mathrm{N}$ & $\mu \mathrm{g} / \mathrm{g}$ & total nitrogen on oven-dry basis & cores, lab analysis \\
\hline $\mathrm{NO}_{3}$ & $\mu \mathrm{g} / \mathrm{g}$ & extractable nitrate-nitrogen on oven-dry basis & cores, lab analysis \\
\hline $\mathrm{NH}_{4}$ & $\mu \mathrm{g} / \mathrm{g}$ & extractable ammonium-nitrogen dry basis & cores, lab analysis \\
\hline FELD & $\mathrm{mm} / \mathrm{yr}$ & sediment deposition on feldspar marker & direct measurement \\
\hline
\end{tabular}

Notes: Data were collected independently at all sites. Abbreviations are GIS, geographic information system, and GPS, geographic positioning system.

and passed through an ASTM No. 10 sieve. Soil and sediment $\mathrm{pH}$ were measured with a glass electrode in a 1:2 soil to water slurry. The field-moist sieved soil was analyzed for $2 \mathrm{~mol} / \mathrm{L} \mathrm{KCl}$ extractable [nitrate + nitrite]$\mathrm{N}\left(\mathrm{NO}_{3}-\mathrm{N}\right)$ and ammonium $\left(\mathrm{NH}_{4}-\mathrm{N}\right)$ on a Bran and Lubbe TRAACS autoanalyzer and for soluble organic carbon $(\mathrm{C})$ and nitrogen $(\mathrm{N})$ with a Shimadzu TOC 5000 solution $\mathrm{C}$ analyzer equipped with a TN module.
Total C and N contents were measured (Carlo-Erba NA 1500 CNS analyzer) and results expressed on a per g dry soil/g sediment basis. Soil phosphorus was determined on perchloric-nitric acids of digested soils (Carter and Gregorich 2007). Three additional soil cores were collected in each of the emergent and riparian vegetation zones and were analyzed for bulk density, texture, and moisture content. Furthermore, three replicate feldspar

TABLE 2. Summary of how well study experimental treatments (temperature and hydrology) captured differences in independent environmental variables including flood duration, rate of water surface rise during flood (POWER), and the depth, duration, and frequency of inundation at location mean elevation of plant transects.

\begin{tabular}{|c|c|c|c|c|c|c|}
\hline Treatment & $N$ & $\begin{array}{c}\text { SGDD } \\
\left({ }^{\circ} \mathrm{C}\right)\end{array}$ & $\begin{array}{l}\text { Duration } \\
\text { (min) }\end{array}$ & $\begin{array}{l}\text { Power } \\
(\mathrm{mm} / \mathrm{h})\end{array}$ & $\begin{array}{l}\text { Depth } \\
\text { (m) }\end{array}$ & $\begin{array}{c}\text { Frequency } \\
\text { (no. floods/yr) }\end{array}$ \\
\hline \multicolumn{7}{|l|}{ Temperature } \\
\hline Warm & 10 & $\begin{array}{r}2550^{\mathrm{a}} \\
(71)\end{array}$ & $\begin{array}{l}397^{\mathrm{b}} \\
(87)\end{array}$ & $\begin{array}{l}121^{\mathrm{a}} \\
(41)\end{array}$ & $\begin{array}{l}0.21^{\mathrm{b}} \\
(0.03)\end{array}$ & $\begin{array}{r}531^{\mathrm{a}} \\
(55)\end{array}$ \\
\hline Reference & 6 & $\begin{array}{r}2079^{6} \\
(43)\end{array}$ & $\begin{array}{r}2367^{\mathrm{a}} \\
(906)\end{array}$ & $\begin{array}{l}55^{\mathrm{b}} \\
(21) \ddagger\end{array}$ & $\begin{array}{l}0.35^{\mathrm{ab}} \\
(0.04)\end{array}$ & $\begin{array}{l}113^{b} \\
(38)\end{array}$ \\
\hline Cold & 8 & $\begin{array}{r}1658^{c} \\
(33)\end{array}$ & $\begin{array}{r}610^{b} \\
(193)\end{array}$ & $\begin{array}{l}236^{\mathrm{a}} \\
(46) \ddagger\end{array}$ & $\begin{array}{r}0.47^{\mathrm{a}} \\
(0.08)\end{array}$ & $\begin{array}{l}479^{a} \\
(62)\end{array}$ \\
\hline \multicolumn{7}{|l|}{ Hydrology $\dagger$} \\
\hline Emergent & 12 & $\begin{array}{r}2147^{\mathrm{a}} \\
(132)\end{array}$ & $\begin{array}{r}1040^{\mathrm{a}} \\
(90) \pm\end{array}$ & $\begin{array}{r}145^{\mathrm{a}} \\
(29)\end{array}$ & $\begin{array}{r}0.35^{\mathrm{a}} \\
(0.05)\end{array}$ & $\begin{array}{r}436^{\mathrm{a}} \\
(68)\end{array}$ \\
\hline Riparian & 12 & $\begin{array}{l}2097^{\mathrm{a}} \\
(127)\end{array}$ & $\begin{array}{l}881^{6} \\
(64) \ddagger\end{array}$ & $\begin{array}{l}141^{\mathrm{a}} \\
(31)\end{array}$ & $\begin{array}{r}0.25^{\mathrm{a}} \\
(0.05)\end{array}$ & $\begin{array}{r}382^{\mathrm{a}} \\
(62)\end{array}$ \\
\hline
\end{tabular}

Notes: Different superscript letters indicate a significant difference using Tukey's method $(P<$ $0.05)$. Values are means with SE in parentheses. Interactions between experimental treatments did not explain independent environmental variables.

$\dagger$ Pairwise $t$ test.

† Log-transformed. 
sedimentation plates were installed at each site to examine annual sediment deposition rates. Water grab samples were collected quarterly at all sites and analyzed for total nitrogen (TN), $\mathrm{NO}_{2}-\mathrm{NO}_{3}$, total phosphorus (TP), and total dissolved phosphorus (TDP).

Soil temperature is often used in ecology as an indicator of the effects of climate on plant productivity, diversity, and competition (Kielland et al. 2006, Bansal and Germino 2008). We selected soil temperature as the best overall integrator of thermal regimes at our sites due to (1) rapid and frequent switching between flooded and drained conditions, (2) rapidly changing water depths, (3) differences in mean depths between sites, and (4) the role of soil temperature as a regulator of spring emergence of noxious plant species (Masin et al. 2005). Use of water temperatures might mean that at any given time we would be comparing air temperatures at a drained location to water temperatures at an inundated site.

Soil temperatures were measured at two different elevations at each site using Onset Computer Corporation Model U22 Water Temperature Pro V2 loggers. A soil temperature logger was installed in each emergent $(N=12)$ and riparian $(N=12)$ hydrology site. The loggers were located in shade free areas at a depth of 10 $\mathrm{cm}$ below the soil surface and programmed at a $15-\mathrm{min}$ logging interval. Soil temperatures were used to calculate cumulative soil growing degree days (SGDD) using Hoboware Pro Software (Onset Computer Corporation, Bourne, Massachusetts, USA), and were used to compare the thermal balances between warm, cold, and reference riparian sites. SGDD measurement is calculated as the integral under the daily diurnal temperature curve; these values are summed over an entire growing season to determine the annual SGDD for a given site. Accumulated SGDD show significant differences in the heat accumulation at our cold, warm, and reference sites (Fig. 2 and Table 2).

These soil temperature differences peaked through the summer growing season as shown by the significant July and August spread in SGDD among sites (Fig. 2) and importantly the same seasonal pattern of large cumulative SGDD temperature differences was shown along an upstream-downstream transition toward ambient temperatures at our cold and warm gradient locations (data not shown). Plants growing at the cold vs. the warm locations were subjected to $35 \%$ lower heat content as measured by annual accumulation of SGDD (Table 2).

We also monitored water quality during quarterly visits in 2009 and 2010 to verify that plant community differences were not primarily driven by watershed nutrient fluxes. Mean nitrogen and phosphorus concentrations at all of our sites were at or below the EPA recommended ambient water quality criteria for both TN $(690 \mu \mathrm{g} / \mathrm{L})$ and TP $(36 \mu \mathrm{g} / \mathrm{L})$ based on the 25 th percentile of aggregate water quality monitoring data for Region IX (EPA 2000). There were no major differences in other constituents (cations and anions) or physical parameters ( $\mathrm{pH}$, conductivity, etc.) between our locations. This indicates that locations in our different temperature treatments had similar water quality and nutrient regimes and confirms that our locations meet our selection criteria as discussed previously in the methods section. The results of our analysis of soil chemical and physical properties were used along with our temperature and hydrologic characteristics in our model assessments to determine the importance of soil chemistry on plant community structure (Appendix A).

Our study design captured river and wetland ecosystems that span expected gradients of temperature and hydrology in scenarios of both past and future climate change including significantly increased summer water temperatures of at least $2-3^{\circ} \mathrm{C}$, increased flood frequencies and increased storm power. Specifically, our experimental treatment locations successfully captured the key features of most future climate scenarios for the southeast United States, which state (1) water temperatures will increase and (2) the frequency and intensity of high flow events will increase (IPCC 2001, Alcamo et al. 2003, MEA 2005, Webster et al. 2005, Ingram et al. 2013). Although we have not increased the drought proneness of our sites, we have increased disturbance because of increased flood power. Table 2 presents a summary of temperature and hydrologic parameters by treatment. These include the number of flood events, average duration of individual flood events, average return period, and the parameter "power" that describes flood power or the average rate of increase in water depth during rising stage $(\mathrm{mm} / \mathrm{h})$. The warm and cold treatment sites are characterized by a frequency of flooding or pulsing hydrology that is five times higher than the reference sites, but floods have shorter flood durations ( $<1$ day vs. nearly 2 days for the reference sites). The parameter power suggests two to four times the flood energy at the cold and warm treatment sites, respectively, than at the reference sites. These differences could be explained by the rapid response of water levels to dam releases compared to the slower response in freeflowing watersheds to precipitation and runoff.

To further investigate the response of the invasive communities at our sites, we summarized the native and exotic (i.e., North American) ranges of the invasive species found at our locations. The latitudinal distribution of the most abundant invasive species from each treatment are summarized with the range of latitudes in which a given species is found in North America, the midpoint of the distribution range for each species, and a weighted mean midpoint for each treatment.

\section{Statistical modeling}

Our primary analysis uses a multivariate regression of environmental variables on a community matrix of plant species abundances. Secondary analyses utilize linear regressions of species richness or dominance vs. environmental variables, or post hoc tests of community indices vs. treatments/factors. All statistical analysis was performed using the $\mathrm{R}$ statistical package 


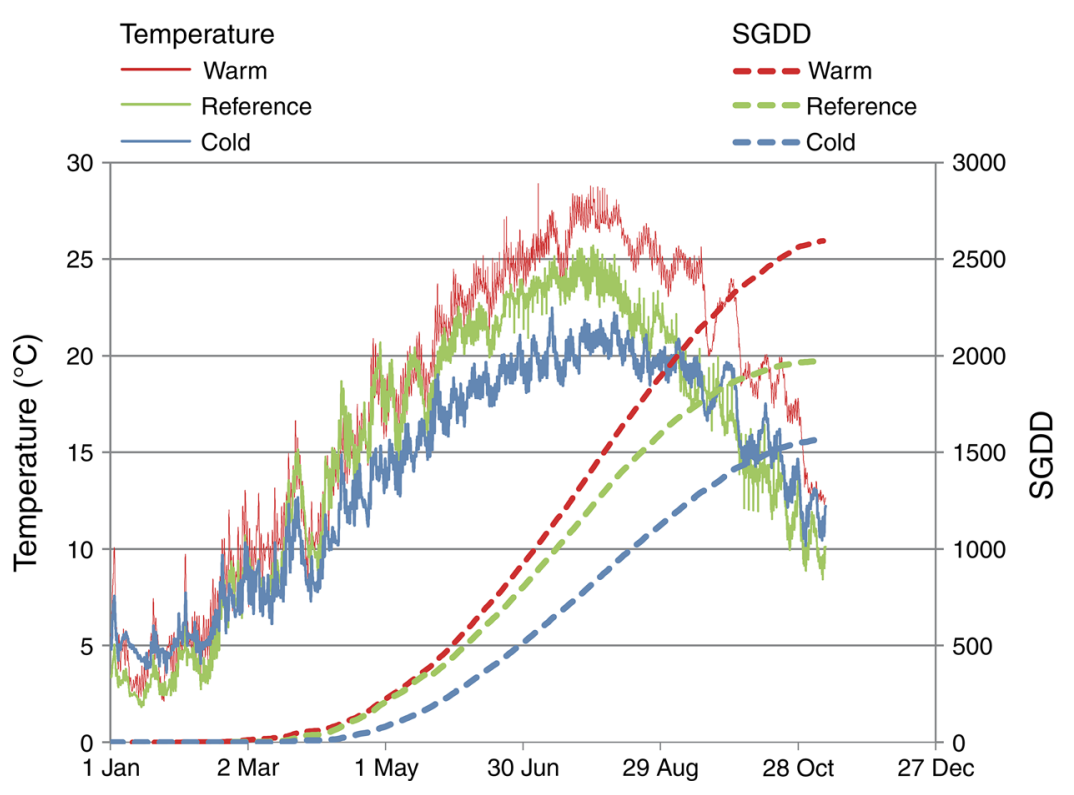

FIG. 2. Soil temperature expressed in ${ }^{\circ} \mathrm{C}$ and as soil growing degree days (SGDD) in ${ }^{\circ} \mathrm{C}$ at our warm (red), reference (green), and cold (blue) gradient sites during 2011. Daily temperature variations are shown and were used to calculate the cumulative SGDD (treatment daily means shown as smooth curved lines of heat accumulation at each site) during the 2011 growing season with SGDD accumulation beginning in late March and ending in early November.

(R Development Core Team 2013) and the vegan library (Oksanen et al. 2012). We began our analysis by selecting a parsimonious set of environmental variables using a forward stepwise regression and eliminating potentially collinear variables where variance inflation factors were $>10$ (Borcard et al. 2011). Our data were conditioned on a matrix of latitude and longitude to control for spatial effects in the variable selection process (Blanchet et al. 2008).

We grouped our environmental variables into three categories: Climate, Site, and Space, to evaluate the relative importance of climatic variables and sitespecific variables in structuring our plant communities, while simultaneously accounting for joint variation and the effects of spatial patterns or "space." The individual explanatory variables included in each category are presented in Table 3. We used variance partitioning to analyze plant community structure using the function varpart.MEM (Legendre et al. 2012) and produce a graphic representation of variance in the form of a Venn diagram. Our variance partition model uses a conservative approach described by Zhang et al. (2013) using Moran's eigenvector maps with PCNM axes (Borcard and Legendre 2002, Borcard et al. 2004, Dray et al. 2006). This procedure avoids statistical issues described by Gilbert and Bennett (2010).

We evaluated the importance of each individual environmental variable in explaining variance in the

TABLE 3. Variance explained (Var.) and statistical significance of explanatory variables in plant community matrix ordination of all species, invasive species, and native species using variables selected with a distance-based partial redundancy analysis (RDA; capscale) model fitted with forward selection process and evaluated using a collinearity criterion.

\begin{tabular}{|c|c|c|c|c|c|c|c|c|c|c|c|}
\hline \multirow[b]{2}{*}{ Variable } & \multirow[b]{2}{*}{ Category } & \multirow[b]{2}{*}{ df } & \multicolumn{3}{|c|}{ All species } & \multicolumn{3}{|c|}{ Invasive only } & \multicolumn{3}{|c|}{ Native only } \\
\hline & & & Var. & $F$ & $P$ & Var. & $F$ & $P$ & Var. & $F$ & $P$ \\
\hline POWER & climate & 1 & 1.586 & 5.037 & 0.001 & 1.298 & 5.294 & 0.001 & 1.699 & 4.943 & 0.001 \\
\hline SGDD & climate & 1 & 1.363 & 4.329 & 0.001 & 0.303 & 1.238 & 0.279 & 1.398 & 4.065 & 0.001 \\
\hline $\mathrm{Ag}$ & site & 1 & 1.099 & 3.490 & 0.001 & 0.952 & 3.883 & 0.002 & 1.135 & 3.301 & 0.001 \\
\hline FREQ & climate & 1 & 0.814 & 2.586 & 0.002 & 0.785 & 3.203 & 0.006 & 0.857 & 2.492 & 0.002 \\
\hline AREA & site & 1 & 1.069 & 3.394 & 0.001 & 1.234 & 5.036 & 0.001 & 0.910 & 2.648 & 0.002 \\
\hline DUR & climate & 1 & 0.605 & 1.920 & 0.015 & 0.434 & 1.769 & 0.086 & 0.685 & 1.993 & 0.016 \\
\hline Sand & site & 1 & 0.461 & 1.463 & 0.082 & 0.516 & 2.106 & 0.046 & 0.479 & 1.393 & 0.122 \\
\hline СТP & site & 1 & 0.380 & 1.207 & 0.221 & 0.549 & 2.238 & 0.033 & 0.395 & 1.150 & 0.273 \\
\hline Residual & & 12 & 3.779 & & & 2.941 & & & 4.125 & & \\
\hline
\end{tabular}

Notes: Spatial variance was partialled out of the model by conditioning with significant components of a Moran's eigenvector map. The number of degrees of freedom is 1 for all explanatory variables and 12 for all residuals. See Table 1 for explanation of variables. Categories used for variance partitioning include Climate (climate altered) and Site (site specific). Bold values are statistically significant at $P<0.05$. 

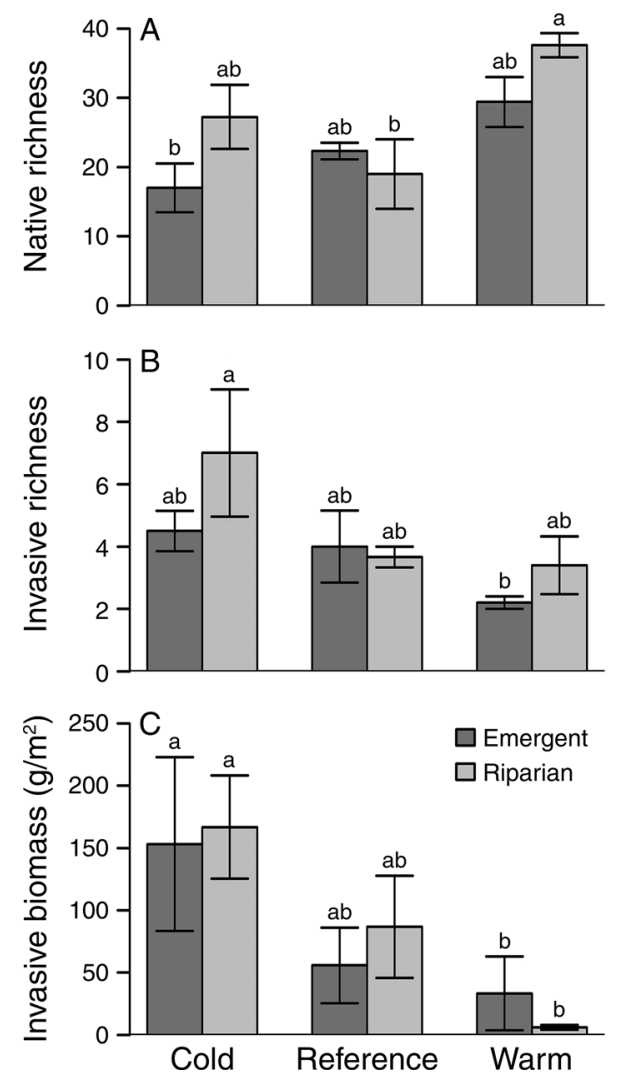

FIG. 3. The trends in our plant community indices across temperature treatments (cold, reference, warm) and hydrology treatments (emergent and riparian): (A) native species richness, (B) invasive species richness, and (C) peak aboveground biomass of invasive species. Bars show mean values \pm SE. Differing lowercase letters above bars indicate statistically significant difference between treatments using Tukey's posthoc test $(P<0.05)$.

community composition matrix representing our sites. We used partial Redundancy Analysis (RDA) to evaluate the significance of environmental variables in explaining invasive species abundance patterns when the effects of latitude and longitude are held constant. All of our RDA analyses were performed using Hellinger transformed species abundance data (Legendre and Gallagher 2001, Borcard et al. 2011). Here we use an asymmetrical form of canonical analysis with a dissimilarity matrix, or distance based RDA (Rao 1964, Legendre and Anderson 1999, Legendre et al. 2005, Legendre 2008) via Constrained Analysis of Principal Coordinates (Capscale) as implemented in the package Vegan (Oksanen et al. 2012).

\section{RESULTS}

\section{Species richness and productivity}

We found a trend of increasing native species richness with increasing temperature from cold, to reference, to warm treatments with significantly higher overall species richness in the warm riparian treatment $(P<0.05)$. We saw an inverse trend when we examined invasive species; with the highest invasive species richness in the cold treatments and the warm emergent treatment having significantly lower invasive species richness (Fig. 3A and B, Appendix B).

We used peak aboveground summer biomass (PAB) as an index of the net productivity and dominance of the emergent plant communities at our sites. We assessed the relationship of temperature and invasive species dominance and found trends of decreased invasive species dominance and relative density with increased temperature (Figs. 3C, 4A, and B, Appendix B). Our cold locations displayed the highest levels of invasion, our warm locations the lowest, and freeflowing reference locations showed intermediate levels of both invasive species richness and dominance (Fig. $3 \mathrm{~B}$ and $\mathrm{C})$. These trends were observed in both absolute invasive PAB (Fig. 4A) and in proportional dominance of invasive species (Fig. 4B). The percentage of invasive species biomass was as much as $50 \%$ at the cold sites compared to a minimum of $5 \%$ at the warm sites. Moreover, as water temperature trended toward ambient levels downstream, the percentage of invasive species dropped sharply at our cold gradient
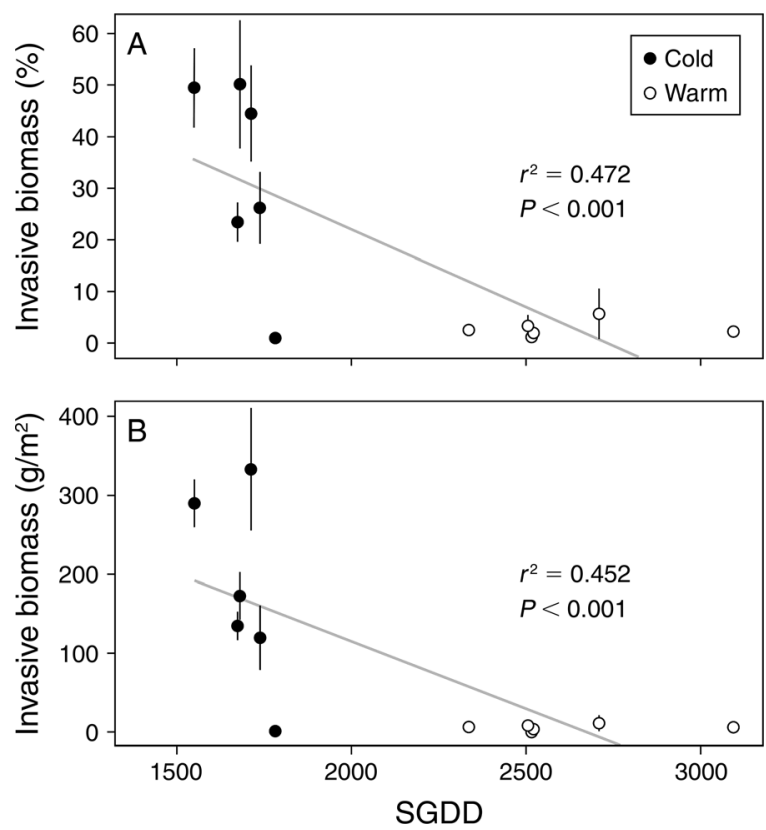

FIG. 4. The relationship between soil growing degree days (SGDD) and invasive species dominance expressed as peak aboveground biomass (PAB) at our cold (black points) and warm (white points) gradient sites (insert 2 in Fig. 1) while minimizing the variability of all other measured environmental predictors within a given warm or cold gradient location. (A) Percentage of $\mathrm{PAB}$ attributed to invasive species in reference to total $\mathrm{PAB}$ of the plant community, (B) absolute $\mathrm{PAB}$ produced by invasive species. Bars represent means \pm confidence interval of biomass samples $(N=3)$. 

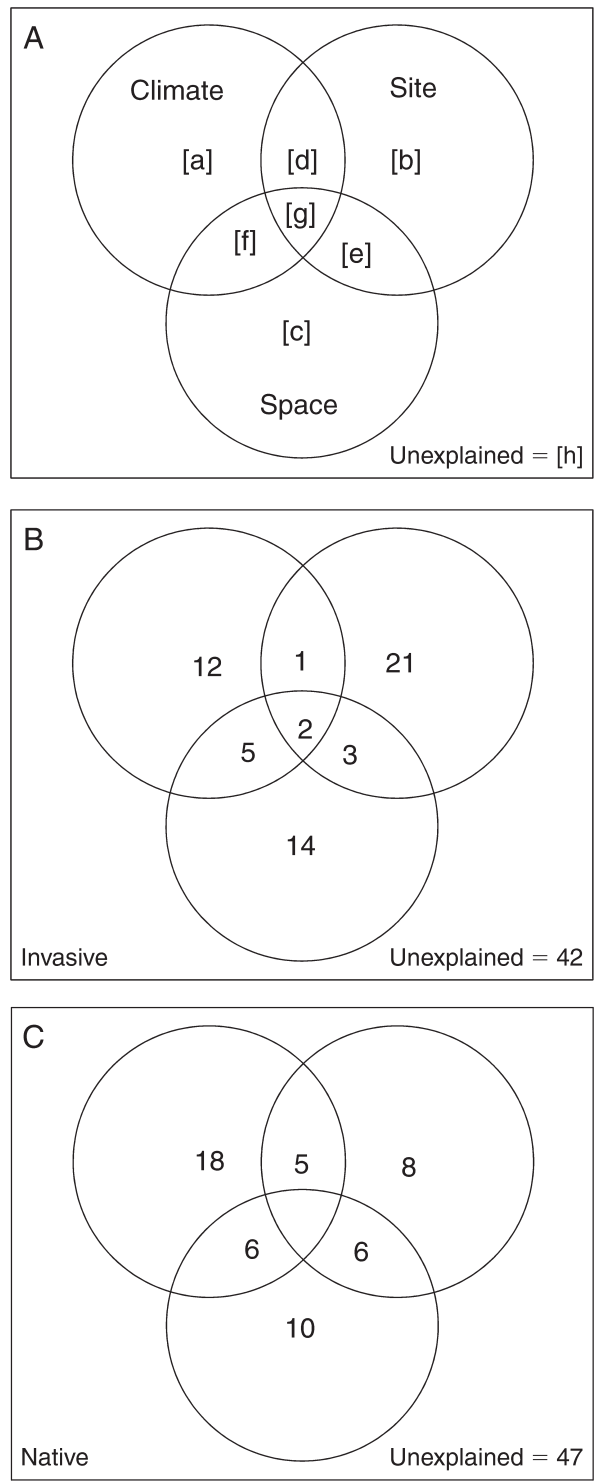

FIG. 5. Venn diagrams showing the (A) symbol key and results of variance partition analysis of the (B) invasive and (C) native plant community matrix; each Venn diagram shows the total variation in community structure as explained by each group of variables while holding the effects of the other groups constant. The presented numbers represent the computed $R^{2}$ multiplied by 100 . (A) Symbol key for the variance partition analysis of three explanatory groups of variables (climate, site, and space; Table 3). The variance explained uniquely by each group is then labeled as a-c, joint variations attributed to two groups are labeled $\mathrm{d}-\mathrm{f}$, and variation attributed jointly to three groups is labeled as $\mathrm{g}$. The final estimate of unexplained variance, $\mathrm{h}$, is based on an adjusted $R^{2}$. (B and C) Variance proportions of less than 1 are not labeled and proportionally adjusted according to methods described by Legendre et al. (2012).

sites despite similar soils, hydrology, watershed, and propagule sources. We also saw a significant linear relationship (adjusted $R^{2}=0.56$ ) between SGDD and the relative frequency of invasive species across all sites (Appendix B).
Differential responses of plants to environmental variables

Variance partitioning (Legendre et al. 2012) was used to evaluate the relative contribution of three groups of variables (Climate, Site, and Space) explaining the variance seen in the native and invasive species components of our community matrix (Fig. 5, Table 3). The Climate group of variables, including SGDD and hydrology, was a stronger independent, predictor of community composition for native than for invasive species, explaining $18 \%$ vs. $12 \%$ of model variance respectively, more so when accounting for joint variation (see labels $\mathrm{d}$ and $\mathrm{f}$ in Fig. 5A). The Site-related variables, such as watershed and soil characteristics, accounted for a much greater proportion of variation in invasive community composition (21\%) than for native community composition (8\%). Spatial variance was of secondary or tertiary importance in both models.

To evaluate the contribution of individual environmental variables to overall community composition, we performed a redundancy analysis (RDA) to create a global model that included all environmental attributes. A partial RDA was performed to remove the effects of spatial covariation using a conditioning matrix of latitude and longitude of our study sites. Our model gives a significant fit between our spatially corrected environmental variables and our species abundance matrix. The summary statistics of model fit are

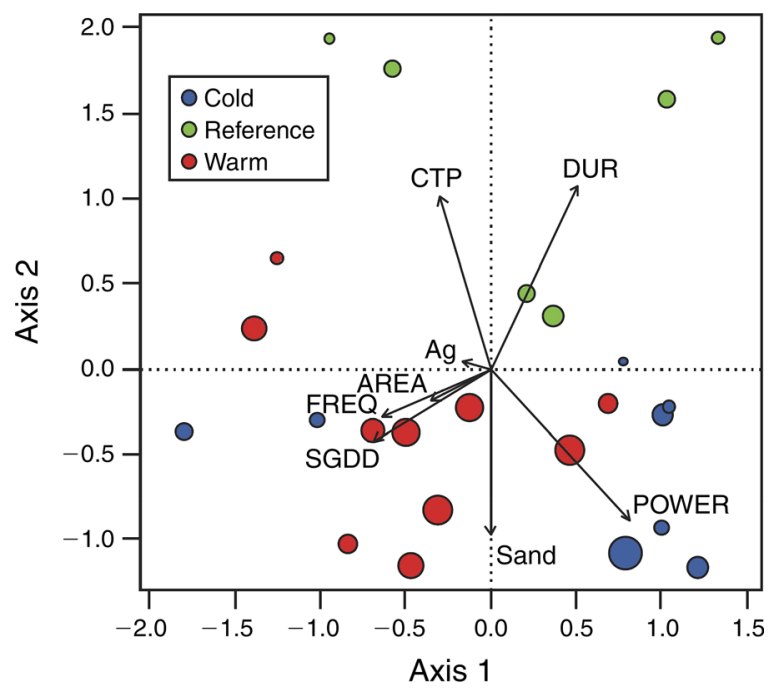

FIG. 6. Partial redundancy analysis (RDA) ordination of site community similarity by warm (red circles), cold (blue circles), and reference (green circles) temperature treatments. Degree of correlation of environmental variables with the axes are shown as vectors whose relative correlations with species space are expressed by length (2008, 2009, and 2010 community data). The sizes of site symbols are scaled by relative species richness. Environmental variables include flood power (POWER), soil growing degree days (SGDD), watershed area (AREA), watershed proportion cultivated (Ag), flood frequency (FREQ), flood depth (DEPTH), flood duration (DUR), soil total P (CTP). The model was conditioned with a spatial matrix (Moran's eigenvector map). 
TABLE 4. Latitudinal ranges of the five most important invasive species seen within our temperature treatments (cold, warm, and reference).

\begin{tabular}{|c|c|c|c|c|c|c|}
\hline Treatment/species & Importance $\dagger$ & $\begin{array}{l}\text { Exotic } \\
\text { range }^{5}\end{array}$ & $\begin{array}{l}\text { Latitudinal } \\
\text { extremes }\end{array}$ & $\begin{array}{l}\text { Latitudinal } \\
\text { range }\end{array}$ & $\begin{array}{l}\text { Range } \\
\text { midpoint }\end{array}$ & Native range \\
\hline \multicolumn{7}{|l|}{ Cold } \\
\hline Mentha $\times$ piperita & 17.6 & $\mathrm{AK}-\mathrm{FL}$ & $65-28$ & 37.0 & 46.5 & Europe $^{4}$ \\
\hline Murdannia keisak & 15.9 & MD-FL & $39-28$ & 11.0 & 33.5 & $\begin{array}{l}\text { Temperate and tropical regions. } \\
\text { Asia }^{2}\end{array}$ \\
\hline Persicaria hydropiper & 9.98 & $\mathrm{AK}-\mathrm{FL}$ & $65-28$ & 37.0 & 46.5 & Europe $^{4}$ \\
\hline Arthraxon hispidus & 7.59 & NY-FL & $43-28$ & 15.0 & 35.5 & $\begin{array}{l}\text { Temperate and tropical regions. } \\
\text { Asia, Australasia }\end{array}$ \\
\hline Myosotis scorpioides & 6.72 & $\mathrm{AK}-\mathrm{GA}$ & $65-33$ & 32.0 & 49.0 & Europe, Asia $^{2}$ \\
\hline $\begin{array}{l}\text { Mean weighted by } \\
\text { importance }\end{array}$ & & & & 26.4 & 41.8 & [Connecticut] \\
\hline \multicolumn{7}{|l|}{ Warm } \\
\hline Murdannia keisak & 6.30 & MD-FL & $39-28$ & 11.0 & 33.5 & $\begin{array}{l}\text { Temperate and tropical regions. } \\
\text { Asia }^{2}\end{array}$ \\
\hline Arthraxon hispidus & 2.40 & NY-FL & $43-28$ & 15.0 & 35.5 & $\begin{array}{l}\text { Temperate and tropical regions. } \\
\text { Asia, Australasia }\end{array}$ \\
\hline Hydrilla verticillata & 1.01 & ME-FL & $45-28$ & 17.0 & 36.5 & Europe; Old World ${ }^{2}$ \\
\hline Ligustrum sinense & 1.24 & $\mathrm{MA}-\mathrm{FL}$ & $42-28$ & 14.0 & 35.0 & China $^{1,3}$ \\
\hline Clematis terniflora & 0.69 & $\mathrm{ON}-\mathrm{FL}$ & $51-28$ & 23.0 & 40.0 & E. and S.E. Asia ${ }^{4}$ \\
\hline $\begin{array}{l}\text { Mean weighted by } \\
\text { importance }\end{array}$ & & & & 13.4 & 34.7 & $\begin{array}{l}\text { [North Carolina-South } \\
\text { Carolina Border] }\end{array}$ \\
\hline \multicolumn{7}{|l|}{ Reference } \\
\hline Murdannia keisak & 26.6 & MD-FL & $39-28$ & 11.0 & 33.5 & $\begin{array}{l}\text { Temperate and tropical regions. } \\
\text { Asia }^{2}\end{array}$ \\
\hline Persicaria hydropiper & 11.1 & AK-FL & $65-28$ & 37.0 & 46.5 & Europe $^{4}$ \\
\hline Echinochloa crus-galli & 6.40 & $\mathrm{QC}-\mathrm{FL}$ & $53-28$ & 25.0 & 40.5 & $\begin{array}{l}\text { Worldwide tropics and warm } \\
\text { temperate regions } s^{1}\end{array}$ \\
\hline Lonicera japonica & 4.10 & $\mathrm{ON}-\mathrm{FL}$ & $51-28$ & 23.0 & 40.0 & E. Asia 1,3 \\
\hline Ligustrum sinense & 2.99 & MA-FL & $42-28$ & 14.0 & 35.0 & China $^{1,3}$ \\
\hline $\begin{array}{l}\text { Mean weighted by } \\
\text { importance }\end{array}$ & & & & 19.1 & 37.5 & [Central Virginia] \\
\hline
\end{tabular}

Notes: Exotic range is the northernmost and the southernmost state/province in North America. Latitudinal extremes represent the latitudinal midpoint of the state/province at the boundaries of distribution. Abbreviations are AK, Alaska; FL, Florida; MD, Maryland; NY, New York; GA, Georgia; ME, Maine; MA, Massachusetts; ON, Ontario; QC, Quebec. Latitudinal range is the numerical difference between the latitudinal extremes. Range midpoint is the median of latitudinal extremes. All numbers are in units of degrees latitude. Native ranges in the eastern United States are placed within brackets and are located at the same latitude as the treatment weighted mean midpoint.

Sources: 1, Bailey et al. (1976); 2, USDA, ARS, National Genetic Resources Laboratory (2012); 3, Rehder (2001); 4, Weakley (2010); 5, USDA, NRCS (2014).

$\dagger$ Importance is based on the sum of absolute frequency and the absolute density of transect measurements. The sum of importance values for all species (native + invasive) in a given treatment block has a maximum value of 200.

presented in Appendix $B$ with the first two axes explaining $47 \%$ of the variation in species-environmental space. Our RDA triplot (Fig. 6) shows an obvious clustering of our warm sites along a gradient with SGDD flood frequency (FREQ), and clustering of our cold sites along a gradient with flood power (POWER) and to a degree against the gradient with SGDD. Our reference sites are partitioned from the dammed sites along Axis 2 in response to gradients in flood duration (DUR) and soil total P (CTP). Watershed size (AREA) is positively associated with warm sites that are dominated by native species. Together, CTP, DUR, and POWER create a state-space that encompass most of the cold and reference sites, where invasive species are more dominant (Figs. 3C and 6). Table 3 presents permutated ANOVA results of the three fitted RDA models for the full community data set (all native species and invasive species); fitted RDA models describe the variance explained by each of our environmental variables. For the Native model, the Climate-related variables POWER and SGDD are the most important predictors of community composition followed by Siterelated variables such as the areal fraction of cultivated land (Ag) and AREA. For the Invasive model, POWER is the strongest predictor of community composition, followed by Site-related variables such as Ag and AREA. Notably, SGDD is ranked second in predictor importance for the Native model and is the least important predictor in the Invasive model. Similarly, CTP and sand fraction (Sand), which are important predictors in the Invasive model, are not statistically significant in the Native model. DUR is significant in the Native model while it is not significant in the Invasive model. Variables related to plant phenology such as temperature (SGDD) and flood timing (FREQ and DUR) explained more variance in the Native model than in the Invasive model (33\% vs. $22 \%$ ). 
We found distinct trends in the latitudinal ranges seen in the five most important invasive species (Table 4) (Richardson and Vymazal 2001). The invasive species at our cold locations originate at latitudes with maximum values of $65^{\circ} \mathrm{N}$ (Central Alaska) with mean range midpoint $42.3^{\circ} \mathrm{N}$ (Massachusetts). In contrast, the invasive species that dominate our warm locations have a maximum northern latitude of $51^{\circ} \mathrm{N}$ (Central Ontario, Canada) with mean range midpoint $34.7^{\circ} \mathrm{N}$ (South Carolina). This is despite the proximity of the headwaters of all locations being within $200 \mathrm{~km}$ of one another, and located along the east face of Blue Ridge Mountain Range. A synthesis of Table 4 with our ordination results (Table 3 and Figs. 5 and 6) suggest the invasive species are less sensitive to temperature regimes than the native community, giving these invasive species a competitive advantage at our cold locations.

We compared the composition of plant communities located in free-flowing rivers (reference treatment) vs. those on located regulated rivers (cold and warm treatments) to evaluate possible effects of dams on community composition. The invasive species compositions of our free-flowing reference site communities were not significantly different from those of our dammed locations, but there are differences in the composition of the native plant communities (Appendix B). This suggests that the river fragmentation may influence the composition of native communities at our locations but has little effect on invasive species recruitment. Because our warm and cold treatments are located downstream of large hydroelectric reservoirs, we expected similar dam effects on hydrochory at both warm and cold treatment locations.

\section{Discussion}

Multiple factors influence the successful establishment of invasive and/or naturalized exotic species. These are typically recognized to include propagule dispersion, founder effects, competition with existing native plant communities, and environmental factors that determine the habitat suitability of a given location (Pearson and Dawson 2003, Clarke and Gaston 2006, Pyšek and Richardson 2006). Several models have explored the interplay between propagule recruitment, seed bank composition, and environmental factors to determine the composition of plant communities in wetlands (van der Valk 1981) and more broadly in Bioclimatic Envelope Models (Berry et al. 2002, Pearson and Dawson 2003). However, native communities vary widely in their vulnerability to climate change depending on the relative sensitivity of native and invasive species to alterations of environmental variables and their ability to adapt to novel climatic conditions (Williams and Jackson 2007, Dawson et al. 2011).

Out results indicate that climate-driven environmental variables have greater explanatory power for native assemblages than invasive assemblages. This suggests the performance of a given native assemblage is most strongly associated with climate-driven environmental variables, such as temperature and hydrology, while the performance of an invasive assemblage is more strongly associated with site-related environmental variables such as nutrient availability and watershed area.

The relationships between species richness and temperature seen in this study are consistent with those seen in studies of biogeography, where links between latitude, temperature, and species richness have been studied since the foundation of ecology as a discipline (Merriam 1894). Naturalized alien species richness decreases as one moves through the mid-latitude temperate zone to subtropical and finally tropical zones (Holdgate 1986, Sax 2001, Pyšek and Richardson 2006). The opposite trend is seen for overall community species richness where the highest species richness is found in the tropics and decreases as one moves toward cooler regions near the poles (Fischer 1960, Pianka 1966, Stevens 1989). The most dominant invasive species at our sites originate from high latitudes and are able to tolerate a wide range of climatic conditions; this pattern is in accordance with Rapoport's Rule (Pianka 1966, Stevens 1989) which states that the latitudinal range of species making up a community becomes wider as one moves away from the equator. Thus, invasive species may have a competitive advantage at our cold sites due to relative insensitivity to temperature regime (Thuiller et al. 2006). Despite the presence of dams, it is plausible that the propagules of the invasive species present at our study sites originate in the cooler conditions found in the mountainous headwaters of our study rivers (Tabacchi et al. 2005). Jansson et al. (2005) found no evidence that dams acted as barriers to plant propagule dispersion, but found that flooded plots had much larger pools of colonizing species and received a larger portion of propagules from long-distances. Nilsson et al. (2010) found that hydrochory may assist in the movement of nonnative species into riparian habitats, but found inconsistent effects of dams on hydrochory. Tabacchi et al. (2005) concluded that local environmental factors outweighed hydrochory in structuring extant riparian vegetation communities. The similarity of the invasive species community at our reference and dammed locations suggest that the dams were not acting as significant barriers to the establishment of invasive species at our sites (Appendix B). However, there are differences in the composition of the native plant communities, suggesting that the river fragmentation may influence the composition of native communities at our sites but has little effect on invasive species recruitment, as suggested by the greater importance of watershed area in the Invasive species model. This might be due to differential dispersion success of invasive species through reservoirs when compared to native species, greater reliance on other dispersal mechanisms, or processes other than propagule dispersal that control the establishment of invasive species at our sites. 
Agricultural land use was another important predictor of community composition at our sites. Thuiller et al. (2007) found that land use change and climate change were the most important drivers affecting biodiversity, both of which are linked to alterations of flood power and duration, which affected the distribution and germination of propagules. Thus, management of land use may be a potential tool for mitigating the effects of climate change on pulsed hydrology and sources of invasive species propagules (Miyawaki 2004, Foxcroft et al. 2011).

Our results echo those of many other studies that find that invasive species have broader environmental tolerances than native species and thus reduced negative performance in response to climate alterations. The mechanism driving this pattern might be the greater phenotypic plasticity of invasive species (Bradley et al. 2010, Wolkovich et al. 2013) that allows for apt shifts in phenology in response to alterations of the seasonal timing of temperature and flood patterns. Temperature (SGDD) and flood duration (DUR) have stronger roles in structuring native communities. Invasive species might have a greater competitive advantage at our cold locations due to their ability to reconcile spring flowering and/or growth onset with cooler temperatures and drawdown patterns. Also, native southern wetland species might have been at a competitive disadvantage at the cold locations where more area was open for aggressive invasions. Dams have created bioclimatic envelopes at both our warm locations and cold locations, but it appears that movement of more cold adapted invasive species, through hydrochory and other transport mechanisms, may have allowed preferential establishment of these species at our cold locations. Native southeastern species show higher performance at our warm locations where they are more competitive with high-latitude invaders.

Our analysis suggests the warmer water temperatures anticipated in future climate predictions could favor native communities under some scenarios (Bradley et al. 2009). A more pertinent implication of this study is the stronger response of native riparian species to climatedriven environmental variables. Patterns of stage and water temperature are currently decoupled on southeastern temperate floodplains, with flood peaks occurring in late winter or early spring while peak water temperatures occur in late summer. However, many regional climate predictions describe a seasonal shift of precipitation from winter to summer or autumn (Karl et al. 2009, Hay et al. 2011, Li et al. 2012, Patterson et al. 2012).

The patterns of synchronization between hydrochory, drawdown, and spring water temperatures will affect the germination and emergence of both native and invasive propagules (Merritt and Wohl 2002, Jansson et al. 2005, Forrest and Miller-Rushing 2010, Wolkovich and Cleland 2010). Invasive species often have a greater ability to make shifts in phenology (Wolkovich et al. 2013) in response to climatic temperature alterations. The interactions between seasonal patterns of water temperature and flooding are likely to profoundly affect the future structure and function of native riparian plant communities. Thus, in future competition between riparian native and invasive plant species, the performance of native species is more likely to be negatively affected by climate, while the performance outcomes of invasive species are more strongly influenced by hydrologic disturbance, land use alterations, and nutrient availability (i.e., secondary responses to climate change). In the face of climate alteration, the battle between native and invasive riparian species can be envisioned as a "war of attrition" rather than a "frontal assault." Assuming high nutrient availability, invasive species will be more tolerant of climatic variability, while altered temperature and hydrologic regimes will place native species at a slight competitive disadvantage that might lead to increasing levels of invasion in riparian wetlands in the southeast United States over time.

ACKNOWLEDGMENTS

This study was funded by grant number 83837010 from the United States Environmental Protection Agency's Science to Achieve Results (STAR) Program to C. J. Richardson at the Duke University Wetland Center (DUWC). We thank DUWC staff including Jonathan Bills and Wes Willis for their support with field work and laboratory analysis. We are grateful to our manuscript reviewers for their comments that greatly improved this document. Finally we thank the U.S. Army Corps of Engineers for their assistance with our study sites.

\section{Literature Cited}

Alcamo, J., P. Döll, T. Henrichs, F. Kaspar, B. Lehner, T. Rösch, and S. Siebert. 2003. Development and testing of the WaterGAP 2 global model of water use and availability. Hydrological Sciences Journal 48:317-337.

Allan, J. D., and M. M. Castillo. 2007. Stream ecology: structure and function of running waters. Second edition. Springer, Dordrecht, The Netherlands.

Bailey, L. H., E. Z. Bailey, and L. H. B. Hortorium. 1976. Hortus third: a concise dictionary of plants cultivated in the United States and Canada. MacMillan, New York, New York, USA.

Bansal, S., and M. Germino. 2008. Carbon balance of conifer seedlings at timberline: relative changes in uptake, storage, and utilization. Oecologia 158:217-227.

Bellard, C., W. Thuiller, B. Leroy, P. Genovesi, M. Bakkenes, and F. Courchamp. 2013. Will climate change promote future invasions? Global Change Biology 19:3740-3748.

Berry, P. M., T. P. Dawson, P. A. Harrison, and R. G. Pearson. 2002. Modelling potential impacts of climate change on the bioclimatic envelope of species in Britain and Ireland. Global Ecology and Biogeography 11:453-462.

Blanchet, F. G., P. Legendre, and D. Borcard. 2008. Forward selection of explanatory variables. Ecology 89:2623-2632.

Borcard, D., F. Gillet, and P. Legendre. 2011. Numerical ecology with R. Springer, New York, New York, USA.

Borcard, D., and P. Legendre. 2002. All-scale spatial analysis of ecological data by means of principal coordinates of neighbour matrices. Ecological Modelling 153:51-68.

Borcard, D., P. Legendre, C. Avois-Jacquet, and H. Tuomisto. 2004. Dissecting the spatial structure of ecological data at multiple scales. Ecology 85:1826-1832. 
Bradley, B. A., D. M. Blumenthal, D. S. Wilcove, and L. H. Ziska. 2010. Predicting plant invasions in an era of global change. Trends in Ecology and Evolution 25:310-318.

Bradley, B. A., M. Oppenheimer, and D. S. Wilcove. 2009. Climate change and plant invasions: restoration opportunities ahead? Global Change Biology 15:1511-1521.

Carter, R., and E. G. Gregorich. 2007. Soil sampling and methods of analysis. Second edition. Taylor and Francis, Boca Raton, Florida, USA.

Catford, J., R. Naiman, L. Chambers, J. Roberts, M. Douglas, and P. Davies. 2013. Predicting novel riparian ecosystems in a changing climate. Ecosystems 16:382-400.

Chapin, F. S., III, et al. 2000. Consequences of changing biodiversity. Nature 405:234-242.

Charalambidou, I., and L. Santamaría. 2002. Waterbirds as endozoochorous dispersers of aquatic organisms: a review of experimental evidence. Acta Oecologica 23:165-176.

Clarke, A., and K. J. Gaston. 2006. Climate, energy and diversity. Proceedings of the Royal Society B 273:2257-2266.

Daehler, C. C. 2003. Performance comparisons of co-occurring native and alien invasive plants: implications for conservation and restoration. Annual Review of Ecology, Evolution, and Systematics 34:183-211.

Dawson, T. P., S. T. Jackson, J. I. House, I. C. Prentice, and G. M. Mace. 2011. Beyond predictions: biodiversity conservation in a changing climate. Science 332:53-58.

Diez, J. M., et al. 2012. Will extreme climatic events facilitate biological invasions? Frontiers in Ecology and the Environment 10:249-257.

Dray, S., P. Legendre, and P. R. Peres-Neto. 2006. Spatial modelling: a comprehensive framework for principal coordinate analysis of neighbour matrices (PCNM). Ecological Modelling 196:483-493.

Easterling, D. R., G. A. Meehl, C. Parmesan, S. A. Changnon, T. R. Karl, and L. O. Mearns. 2000. Climate extremes: observations, modeling, and impacts. Science 289:2068-2074.

EPA. 2000. Ambient water quality criteria recommendations information supporting the development of state and tribal nutrient criteria rivers and streams in nutrient Ecoregion IX. United States Environmental Protection Agency, Office of Water, Washington, D.C., USA.

Fischer, A. G. 1960. Latitudinal variations in organic diversity. Evolution 14:64-81.

Forrest, J., and A. J. Miller-Rushing. 2010. Toward a synthetic understanding of the role of phenology in ecology and evolution. Philosophical Transactions of the Royal Society B 365:3101-3112.

Foxcroft, L. C., V. Jarošík, P. Pyšek, D. M. Richardson, and M. Rouget. 2011. Protected-area boundaries as filters of plant invasions. Conservation Biology 25:400-405.

Gilbert, B., and J. R. Bennett. 2010. Partitioning variation in ecological communities: do the numbers add up? Journal of Applied Ecology 47:1071-1082.

Griffith, G., J. Omernik, and J. Comstock. 2002. Ecoregions of North Carolina. United States Environmental Protection Agency, Office of Research and Development, National Health and Environmental Effects Research Laboratory (NHEERL), Western Ecology Division, Corvallis, Oregon, USA.

Hay, L. E., S. L. Markstrom, and C. Ward-Garrison. 2011. Watershed-scale response to climate change through the twenty-first century for selected basins across the United States. Earth Interactions 15:1-37.

Heino, J., R. Virkkala, and H. Toivonen. 2009. Climate change and freshwater biodiversity: detected patterns, future trends and adaptations in northern regions. Biological Reviews 84:39-54.
Hellmann, J. J., J. E. Byers, B. G. Bierwagen, and J. S. Dukes. 2008. Five potential consequences of climate change for invasive species. Conservation Biology 22:534-543.

Holdgate, M. W. 1986. Summary and conclusions: characteristics and consequences of biological invasions. Philosophical Transactions of the Royal Society B 314:733-742.

Hurlbert, S. H. 1984. Pseudoreplication and the design of ecological field experiments. Ecological Monographs 54:187211.

Ingram, K., K. Dow, L. Carter, and J. Anderson. 2013. The effects of climate change on natural ecosystems of the southeast USA. Pages 237-270 in K. Ingram, K. Dow, L. Carter, and J. Anderson, editors. Climate of the southeast United States. Island Press, Washington, D.C., USA.

IPCC. 2001. Climate change 2001: the scientific basis. Contribution of working group I to the third assessment report of the intergovernmental panel on climate change. Cambridge University Press, Cambridge, UK.

Jansson, R., U. Zinko, D. M. Merritt, and C. Nilsson. 2005. Hydrochory increases riparian plant species richness: a comparison between a free-flowing and a regulated river. Journal of Ecology 93:1094-1103.

Johansson, M. E., C. Nilsson, and E. Nilsson. 1996. Do rivers function as corridors for plant dispersal? Journal of Vegetation Science 7:593-598.

Johns, T. C., R. E. Carnell, J. F. Crossley, J. M. Gregory, J. F. B. Mitchell, C. A. Senior, S. F. B. Tett, and R. A. Wood. 1997. The second Hadley Centre coupled oceanatmosphere GCM: model description, spinup and validation. Climate Dynamics 13:103-134.

Junk, W. J., P. B. Bayley, and R. E. Sparks. 1989. The flood pulse concept in river-floodplain systems. Canadian Special Publication of Fisheries and Aquatic Sciences 106:110-127.

Karl, T. R., J. M. Melillo, and T. C. Peterson. 2009. Global climate change impacts in the United States. Cambridge University Press, Cambridge, UK.

Kielland, K., K. Olson, R. W. Ruess, and R. D. Boone. 2006. Contribution of winter processes to soil nitrogen flux in taiga forest ecosystems. Biogeochemistry 81:349-360.

Legendre, P. 2008. Studying beta diversity: ecological variation partitioning by multiple regression and canonical analysis. Journal of Plant Ecology 1:3-8.

Legendre, P., and M. J. Anderson. 1999. Disturbance-based redundancy analysis: testing multispecies responses in multifactorial ecological experiments. Ecological Monographs 69:1-24.

Legendre, P., D. Borcard, and P. R. Peres-Neto. 2005. Analyzing beta diversity: partitioning the spatial variation of community composition data. Ecological Monographs 75:435-450.

Legendre, P., D. Borcard, and D. W. Roberts. 2012. Variation partitioning involving orthogonal spatial eigenfunction submodels. Ecology 93:1234-1240.

Legendre, P., and E. Gallagher. 2001. Ecologically meaningful transformations for ordination of species data. Oecologia 129:271-280.

Leuven, R. E. W., G. Velde, I. Baijens, J. Snijders, C. Zwart, H. J. R. Lenders, and A. Vaate. 2009. The river Rhine: a global highway for dispersal of aquatic invasive species. Biological Invasions 11:1989-2008.

Li, L., W. Li, and Y. Kushnir. 2012. Variation of the North Atlantic subtropical high western ridge and its implication to southeastern United States summer precipitation. Climate Dynamics 39:1401-1412.

Masin, R., M. C. Zuin, D. W. Archer, F. Forcella, and G. Zanin. 2005. WeedTurf: a predictive model to aid control of annual summer weeds in turf. Weed Science 53:193-201. 
MEA. 2005. Ecosystems and human well-being: our human planet. Synthesis and summary for decision makers. Millenium Ecosystem Assessment, Island Press, Washington, D.C., USA.

Merriam, C. H. 1894. Laws of temperature control of the geographic distribution of terrestrial animals and plants. National Geographic Magazine 6:229-238.

Merritt, D. M., and E. E. Wohl. 2002. Progresses governing hydrochory along rivers: hydraulics, hydrology, and dispersal phenology. Ecological Applications 12:1071-1087.

Miyawaki, S. 2004. Invasive alien plant species in riparian areas of Japan: the contribution of agricultural weeds, revegetation species and aquacultural species. Global Environmental Research 8:89-101.

Mohseni, O., T. R. Erickson, and H. G. Stefan. 1999. Sensitivity of stream temperatures in the United States to air temperatures projected under a global warming scenario. Water Resources Research 35:3723-3733.

Mulholland, P. J., et al. 1997. Effects of climate change on freshwater ecosystems of the south-eastern United States and the Gulf Coast of Mexico. Hydrological Processes 11:949970.

Murray, J. V., K. E. Stokes, and R. D. van Klinken. 2012. Predicting the potential distribution of a riparian invasive plant: the effects of changing climate, flood regimes and landuse patterns. Global Change Biology 18:1738-1753.

Naiman, R. J., and H. Décamps. 1997. The ecology of interfaces: riparian zones. Annual Review of Ecology and Systematics 28:621-658.

Nilsson, C., R. L. Brown, R. Jansson, and D. M. Merritt. 2010. The role of hydrochory in structuring riparian and wetland vegetation. Biological Reviews 85:837-858.

Nilsson, C., M. Gardfjell, and G. Grelsson. 1991. Importance of hydrochory in structuring plant communities along rivers. Canadian Journal of Botany 69:2631-2633.

Oksanen, J., et al. 2012. vegan: community ecology package. R package version 2.0-3. http://cran.r-project.org/web/ packages/vegan/

Olmsted, L. L., and J. W. Bolin. 1996. Aquatic biodiversity and the electric utility industry. Environmental Management 20:805-814.

Parmesan, C., and G. Yohe. 2003. A globally coherent fingerprint of climate change impacts across natural systems. Nature 421:37-42.

Parry, M. L. 2007. Climate change 2007: impacts, adaptation and vulnerability. Working group II contribution to the fourth assessment report of the Intergovernmental Panel on Climate Change (IPCC). Cambridge University Press, Cambridge, UK.

Patterson, L. A., B. Lutz, and M. W. Doyle. 2012. Streamflow changes in the South Atlantic, United States during the mid- and late 20th Century. Journal of the American Water Resources Association 48:1126-1138.

Pearson, R. G., and T. P. Dawson. 2003. Predicting the impacts of climate change on the distribution of species: are bioclimate envelope models useful? Global Ecology and Biogeography 12:361-371.

Pianka, E. R. 1966. Latitudinal gradients in species diversity: a review of concepts. American Naturalist 100:33-46.

Pilgrim, J. M., X. Fang, and H. G. Stefan. 1998. Stream temperature correlations with air temperatures in Minnesota: implications for climate warming. Journal of the American Water Resources Association 34:1109-1121.

Pimentel, D., R. Zuniga, and D. Morrison. 2005. Update on the environmental and economic costs associated with alieninvasive species in the United States. Ecological Economics $52: 273-288$
Pollock, M. M., R. J. Naiman, and T. A. Hanley. 1998. Plant species richness in riparian wetlands: a test of biodiversity theory. Ecology 79:94-105.

Pyšek, P., et al. 2010. Contrasting patterns in the invasions of European terrestrial and freshwater habitats by alien plants, insects and vertebrates. Global Ecology and Biogeography 19:317-331.

Pyšek, P., and K. Prach. 1993. Plant invasions and the role of riparian habitats: a comparison of four species alien to Central Europe. Journal of Biogeography 20:413-420.

Pyšek, P., and D. M. Richardson. 2006. The biogeography of naturalization in alien plants. Journal of Biogeography 33:2040-2050

R Development Core Team. 2013. R: a language and environment for statistical computing. R Foundation for Statistical Computing, Vienna, Austria. http://www. R-project.org/

Rahel, F. J., and J. D. Olden. 2008. Assessing the effects of climate change on aquatic invasive species. Conservation Biology 22:521-533.

Rao, C. 1964. The use and interpretation of principal component analysis in applied research. Sankhyā: The Indian Journal of Statistics, Series A 26:329-358.

Rehder, A. 2001. Manual of cultivated trees and shrubs hardy in North America: exclusive of the subtropical and warmer temperate regions. Blackburn Press, Caldwell, New Jersey, USA.

Richardson, C. J., and J. Vymazal. 2001. Sampling macrophytes in wetlands. Pages 297-348 in R. B. Rader, D. P. Batzer, and S. A. Wissinger, editors. Bioassessment and management of North American freshwater wetlands. Wiley, New York, New York, USA.

Richardson, D. M., P. M. Holmes, K. J. Esler, S. M. Galatowitsch, J. C. Stromberg, S. P. Kirkman, P. Pyšek, and R. J. Hobbs. 2007. Riparian vegetation: degradation, alien plant invasions, and restoration prospects. Diversity and Distributions 13:126-139.

Sala, O. E., et al. 2000. Global biodiversity scenarios for the year 2100. Science 287:1770-1774.

Säumel, I., and I. Kowarik. 2010. Urban rivers as dispersal corridors for primarily wind-dispersed invasive tree species. Landscape and Urban Planning 94:244-249.

Sax, D. F. 2001. Latitudinal gradients and geographic ranges of exotic species: implications for biogeography. Journal of Biogeography 28(1):139-150.

Schindler, D. W. 1997. Widespread effects of climatic warming on freshwater ecosystems in North America. Hydrological Processes 11:1043-1067.

SEEPC. 1996. Invasive exotic pest plants in Tennessee (19 October 1999). Research Committee of the Tennessee Exotic Pest Plant Council and Southeast Exotic Pest Plant Council, Oak Ridge, Tennessee, USA.

Shaver, G. R., et al. 2000. Global warming and terrestrial ecosystems: a conceptual framework for analysis. BioScience 50:871-882.

Stevens, G. C. 1989. The latitudinal gradient in geographical range: how so many species coexist in the tropics. American Naturalist 133:240-256.

Tabacchi, E., A.-M. Planty-Tabacchi, L. Roques, and E. Nadal. 2005. Seed inputs in riparian zones: implications for plant invasion. River Research and Applications 21:299-313.

Thuiller, W., D. M. Richardson, and G. F. Midgley. 2007. Will climate change promote alien plant invasions? Pages 197-211 in W. Nentwig, editor. Biological invasions. Ecological Studies, Volume 193. Springer-Verlag, Berlin, Germany.

Thuiller, W., D. M. Richardson, M. Rouget, Ş. Procheş, and J. R. U. Wilson. 2006. Interactions between environment, 
species traits and human uses describe patterns of plant invasions. Ecology 87:1755-1769.

USDA (United States Departement of Agriculture), ARS (Agricultural Research Service), and National Genetic Resources Laboratory. 2012. Germplasm Resources Information Network. National Germplasm Resources Laboratory, Beltsville, Maryland, USA.

USDA (United States Department of Agriculture) and NRCS (Natural Resources Conservation Service). 2014. The PLANTS Database. National Plant Data Team, Greensboro, North Carolina, USA. http://plants.usda.gov

van der Valk, A. G. 1981. Succession in wetlands: a Gleasonian approach. Ecology 62:688-696.

Vilà, M., J. L. Espinar, M. Hejda, P. E. Hulme, V. Jarošík, J. L. Maron, J. Pergl, U. Schaffner, Y. Sun, and P. Pyšek. 2011. Ecological impacts of invasive alien plants: a meta-analysis of their effects on species, communities and ecosystems. Ecology Letters 14:702-708.

Vitousek, P. M., H. A. Mooney, J. Lubchenco, and J. M. Melillo. 1997. Human domination of Earth's ecosystems. Science 277:494-499.

Vörösmarty, C. J., P. Green, J. Salisbury, and R. B. Lammers. 2000. Global water resources: vulnerability from climate change and population growth. Science 289:284288.

Walther, G.-R., E. Post, P. Convey, A. Menzel, C. Parmesan, T. J. C. Beebee, J.-M. Fromentin, O. Hoegh-Guldberg, and F. Bairlein. 2002. Ecological responses to recent climate change. Nature 416:389.
Weakley, A. S. 2010. Flora of the southern and mid-Atlantic states. University of North Carolina Herbarium, North Carolina Botanical Garden, University of North Carolina, Chapel Hill, North Carolina, USA.

Webster, P. J., G. J. Holland, J. A. Curry, and H.-R. Chang. 2005. Changes in tropical cyclone number, duration, and intensity in a warming environment. Science 309:18441846.

Williams, J. W., and S. T. Jackson. 2007. Novel climates, noanalog communities, and ecological surprises. Frontiers in Ecology and the Environment 5:475-482.

Williams, S. E., L. P. Shoo, J. L. Isaac, A. A. Hoffmann, and G. Langham. 2008. Towards an integrated framework for assessing the vulnerability of species to climate change. PLoS Biology 6:e325.

Wolkovich, E. M., and E. E. Cleland. 2010. The phenology of plant invasions: a community ecology perspective. Frontiers in Ecology and the Environment 9:287-294.

Wolkovich, E. M., T. J. Davies, H. Schaefer, E. E. Cleland, B. I. Cook, S. E. Travers, C. G. Willis, and C. C. Davis. 2013. Temperature-dependent shifts in phenology contribute to the success of exotic species with climate change. American Journal of Botany 100:1407-1421.

Zedler, J. B., and S. Kercher. 2004. Causes and consequences of invasive plants in wetlands: opportunities, opportunists, and outcomes. Critical Reviews in Plant Sciences 23:431-452.

Zhang, H., B. Gilbert, X. Zhang, and S. Zhou. 2013. Community assembly along a successional gradient in subalpine meadows of the Qinghai-Tibetan Plateau, China. Oikos 122:952-960.

\section{Supplemental Material}

\section{Ecological Archives}

Appendices A and B are available online: http://dx.doi.org/10.1890/14-0767.1.sm 